to prepare a careful hand to attend the feeding of them, for upon this depends the whole success of the attempt". The Society concerned itself with fisheries and manufactures in addition to its main objective. It did not survive the upheaval of 1745 , but for twenty years supplied a need which more permanent societies were later to satisfy.

\section{Research in Germany}

TrE issue of Die Naturwissenschaften for May 26 is devoted to the work of the Kaiser Wilhelm Gesellschaft zur Forderung der Wissenschaften and extends to more than eighty pages. The year ending March 1933 has been a difficult one for the society, and the hope is expressed that the Government will in the future be able to afford it more financial support. Its membership is now 786, a fall of more than 40 on the year. Its headquarters-Harnack Houseprovides accommodation for the meetings of more than thirty societies in addition to those of its own sections, daily meals for 160 scientific workers, and has put up for short stays 230 visitors during the year. Evening lectures, by distinguished members of the staff, have been given both at headquarters and in other towns of Germany as in previous years. In addition to outline reports of the work of each Institute, lists of papers published by the staffs are given, and both show how much the society is doing by scientific research to increase the welfare of Gernany and to maintain its position amongst those bent on "improving natural knowledge".

\section{Annual Meeting of the French Chemical Society}

Tre French Chemical Society is holding its annual general meeting in Paris on June 15-17; at the same time it is commemorating the bicentenary of the birth of Priestley. Among the distinguished foreign visitors at the meeting are Sir William Pope, professor of chemistry in the University of Cambridge, who has been asked to preside over the opening meeting; Prof. Morgan, president of the Chemical Society ; Prof. H. E. Armstrong; Prof. J. Böeseken, professor of organic chemistry in the Technical High School at Delft, who is speaking on the configuration of the polyalcohols; and Prof. E. Spath, professor of chemistry in the University of Vienna, who is discussing recent syntheses of alkaloids. An address on "Priestley and his scientific Work" was to be given on June 15 by Prof. C. Matignon, professor of inorganic chemistry in the Collège de France, and president of the Society. Priestley, by a decision of the National Council, was made a French citizen and was a member of the Academy of Sciences.

\section{"Empire Forestry Handbook"}

THE Empire Forestry Association has recently published a new edition of the "Empire Forestry Handbook" (Empire Forestry Association, Grand Buildings, Trafalgar Square, London. 5s.). The handbook contains much useful information, including a list of the officers and members of the Empire Forestry Association, and forestry officers serving in different parts of the British Empire. This is followed by a digest of education and research in forestry throughout the Empire, including lists of the universities and research institutes which contain forestry departments, together with the heads of departments and research workers. A list of forest periodicals is appended. The section on forest resources of the Empire contains a wealth of useful statistics concerning forest areas, and production, exports, etc., of conifers and hardwoods. The "Handbook" concludes with a list of the trade and botanical names of Empire timbers.

\section{Lister Institute of Preventive Medicine}

THE report of the governing body, presented at the annual general meeting of the Lister Institute of Preventive Medicine on May 24, gives a survey of the scientific work carried out during the year in the various departments. This includes studies on the viruses of variola, vaccinia, and varicella by Drs. Ledingham and Amies, on the typhus group of diseases by Dr. Felix, and researches on nutrition and vitamins in the Division of Nutrition under Dr. Harriette Chick. The nature and function of phosphoric esters formed during alcoholic fermentation have been studied by Prof. Robison and his collaborators. The National Collection of Type Cultures is housed in the Institute, and more than 5,000 strains of bacteria and fungi have been distributed to workers at home and abroad, and some 200 types have been added to the collection. The total expend. iture for the year was $£ 43,258$, and the excess of income over expenditure $£ 10,362$.

\section{National Institute for Research in Dairying}

THE annual report for the year ending July 31 . 1932, of the National Institute for Research in Dairying, University of Reading, which has only recently been issued, gives a summary of the research work carried out in the various departments. This includes a study of typical English milk, experiments on the feeding of young dairy cattle, and details of schemes for controlling the cleanliness of milk delivered by producers to retailers. Dr. H. Davenport Kay has been appointed to succeed the late Dr. Stenhouse Williams as director of the Institute. The financial position remains substantially the same as in the previous year, and additional income is still needed to stabilise the present position, and without reference to the ultimate needs of the Institute.

\section{Franklin Institute Medals}

Among the medal awards recently made by the Franklin Institute, Pennsylvania, are the following : Franklin medal, founded in 1914 by Mr. Samuel Insull, of Chicago, and awarded to those workers in physical science or technology whose efforts have done most to advance a knowledge of physical science or its application, to Dr. Orville Wright, of Dayton, Ohio, in recognition of the valuable investigations carried out by him and his brother, Wilbur, from which they obtained the first reliable scientific data 
concerning the principles of flight and the design of aeroplanes; and also to Dr. Paul Sabatier, dean of the Faculty of Seience of the University of Toulouse, in recognition of his contributions to the general field of chemistry and especially to organic chemistry, in which he discovered the eatalytic activity of finely divided common metals and devised methods for their use in science and industry; Elliott Cresson medal, founded in 1848 by Mr. Elliott Cresson, to Señor Juan de la Cierva, of London, in consideration of the original conceptions and inventive ability which have resulted in the creation and development of the autogiro.

\section{Announcements}

Prof. F. G. Donnan, professor of general chemistry in the University of London, was elected an honorary member of the Bunsen Society at its thirty-eighth annual meeting held at Carlsruhe on May 26-28.

Prof. E. W. MacBride, professor of zoology in the Imperial College of Science and Technology, has been appointed by the Development Commissioners to be chairman of their Advisory Committee on Fishery Research in succession to the late Prof. G. C. Bourne.

The following appointments in the Colonial Agricultural Service have recently been made by the Secretary of State for the Colonies:-Mr. A. M. Gwynn, to be entomologist in the Department of Agriculture, Nigeria; Mr. C. L. Willding-Jones, to be assistant superintendent of agriculture, Cold Coast.

Iт is announced in Science of May 19 that the Rumford medal of the American Academy of Arts and Sciences has been awarded to Dr. Harlow Shapley, director of the Harvard College Observatory and Paine professor of astronomy in Harvard University, for "researches on the luminosity of stars and galaxies".

IT is announced by Science Service that Commdr. Jerome Clarke Hunsaker, now vice-president of the Goodyear-Zeppelin Corporation, Akron, who designed the first modern airships produced in the United States, has been awarded the 1933 Daniel Guggenheim medal. Commdr. Hunsaker introduced aerodynamic research into American aircraft design by translating Eiffel's pioneer work and building the first wind tunnel at the Massachusetts Institute of Technology. He designed the Shenandoah airship and the first modern non-rigid airships in the United States. Since resigning from the Navy in 1927, he has played an important part in the production of the Akron and the Macon.

A piscussion on "The Ionosphere", to be opened by Prof. E. V. Appleton, will take place at the Royal Society on June 22 at 4.30 p.m.

THE Masters' memorial lectures of the Royal Horticultural Society will be delivered in the lecture room of the Society's new hall in Greycoat Street,
Westminster, on July 18 and 19 , at 3.30 p.m., by Prof. V. H. Blackman, on "Plants in Relation to Light and Temperature".

Is 1920, Miss L. Jones-Bateman of Cae Glass, Abergele, presented to the Royal Horticultural Society a valuable silver-gilt replica of the Warwick Vase to be used for the encouragement of fruit production. It is accordingly decided to offer it triennially for researches in the growing of hardy fruits, figs, grapes and peaches in the open or under glass, and it is available for award in 1933. Candidates should submit accounts of their work by October 31 to the Secretary, Royal Horticultural Society, Vincent Square, Westminster, London, S.W.I.

The life story of William and Caroline Herschel has been compiled from their journals and letters by Lady Lubbock, the granddaughter of Sir William Hershal, and will be published in July under the title "The Herschel Chronicle", by the Cambridge University Press. The book presents so far as possible in their own words, the astronomical discoveries of the Herschels.

Applications are invited for the following appointments, on or before the dates mentioned :-An organiser of further education and a principal of the Stratford-on-Avon Technical and Art School-.The Director of Education, 22, Northgate Street, Warwick (June 19). A chief sanitary inspector for the Municipal Commissioners, Penang-Messrs. Peirce and Williams, 1, Victoria Street, Westminster, S.W.1 (June 21). A University professor of pathology at the London (Royal Free Hospital) School of Medicine for Women-The Academic Registrar, University of London (June 23). A probationary forest officer for H.M. Forestry Commissioners-The Secretary, Forestry Commission, 9, Savile Row, London, W.1 (June 24). A lecturer in experimental psychology at the University of St. Andrews-The Secretary (June 24). A demonstrator in botany, interested in mycology, at King's College, Strand, London, W.C.2 -The Secretary (June 27). A head of the Mathe. matics and Physics Department of the Liverpool Central Municipal Technical School-The Director of Education, 14, Sir Thomas Street, Liverpool, 1 (July 3). A junior assistant in the Electrical Engineering Department of the Royal Technical College, Glasgow-The Professor of Electrical Engineering (July 10). Examiners in various scientific subjects in the General and Higher School Examinations of the University of London-The Secretary to the Matriculation and School Examinations Council, University of London, South Kensington, S.IV.7 (July 21). A professor of economics and commerce, and a professor of education at University College, Hull--The Registrar. A teacher of cookery at the Gloucestershire Training College of Domestic Science, Barrack Square, Gloucester--The Principal. A mechnnical engineer for water works for the Government of the United Provinces, India-The High Commissioner for India, General Department, India House, Aldwych, W.C.2. A lecturer in botany at the Midland Agricultural College, Sutton Bonington, Loughborough. 